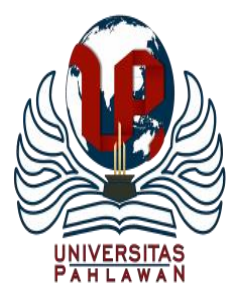

Jurnal Abdidas Volume 1 Nomor 5 Tahun 2020 Halaman 430 - 435

JURNAL ABDIDAS

http://abdidas.org/index.php/abdidas

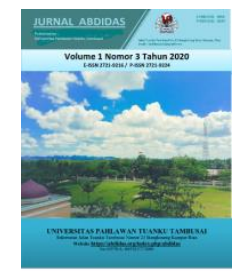

\title{
Sosialisasi Gerakan Masyarakat Cerdas Menggunakan Masker Dimasa Pandemi Guna Mencegah Penyebaran Virus COVID-19
}

\author{
Puspa Ningrum ${ }^{1}$, Husni Mubarak ${ }^{2}$, Tyagita Widya Sari $^{3}$, Husnah $^{4}$ \\ Universitas Abdurrab, Pekanbaru, Indonesia ${ }^{1,2,3,4}$ \\ E-mail : puspa.ningrum@univrab.ac.id ${ }^{1}$ husni.mubarak@univrab.ac.id ${ }^{2}$ tyagita.ws@univrab.ac.id ${ }^{3}$ \\ husnah@univrab.ac.id
}

\begin{abstract}
Abstrak
Masyarakat di Kelurahan Sialang Munggu hidup secara bergotong royong dan terbiasa berinteraksi antar sesama warganya. Semenjak pandemi COVID-19 melanda Indonesia, banyak daerah-daerah yang terkena dampaknya, tak terkecuali Kelurahan Sialang Munggu. Dengan adanya pandemi COVID-19 ini sangat berdampak terhadap aktivitas warga di Kelurahan Sialang Munggu, sehingga kegiatan-kegiatan sosial banyak yang terhenti. Berbagai macam upaya untuk mengantisipasi penyebaran virus COVID-19 sudah dilakukan oleh pemerintah salah satunya dengan mengeluarkan kebijakan tentang pedoman perilaku hidup baru dimasa pandemi COVID-19. Penggunaan masker menjadi langkah antisipasi awal yang dimulai dari diri sendiri. Oleh karena itu, dilaksanakanlah sosialisasi gerakan masyarakat cerdas menggunakan masker. Hal ini tentunya diharapkan masyarakat dapat selalu disiplin menerapkan protokol kesehatan selama pandemi COVID-19. Kegiatan pengabdian masyarakat ini dilakukan dalam bentuk sosialisasi terhadap masyarakat di Kelurahan Sialang Munggu dengan mendatangi rumah-rumah warga dan mendatangi pasar dengan menggunakan metode ceramah. Selanjutnya dilanjutkan dengan menyebarkan brosur berisi pentingnya menggunakan masker dan menerapkan protokol kesehatan COVID-19, serta diakhiri dengan pembagian masker gratis. Berdasarkan kegiatan yang telah dilakukan dapat disimpulkan bahwa kegiatan pengabdian ini dapat meningkatkan pemahaman masyarakat mengenai pentingnya menggunakan masker dimasa pandemi COVID-19. Sehingga untuk selanjutnya kualitas kehidupan masyarakat akan meningkat.
\end{abstract}

Kata kunci: cerdas menggunakan masker, COVID-19, kelurahan sialang munggu, kehidupan baru

\section{Abstract}

The citizen in Kelurahan Sialang Munggu live together and are used to interacting with fellow citizens. Since the COVID19 pandemic hit Indonesia, many areas have been affected, including Kelurahan Sialang Munggu. With the COVID-19 pandemic, it has had an impact on the activities of residents in Kelurahan Sialang Munggu, so that many social activities have stopped. Various kinds of efforts to anticipate the spread of the COVID-19 virus have been carried out by the government, one of which is by issuing policies on guidelines for new life behaviors during the COVID-19 pandemic. The use of masks is an early anticipatory step that starts with yourself. Therefore, the socialization of smart community movements using masks was carried out. This is of course expected that the public can always be disciplined in implementing health protocols during the COVID-19 pandemic. This community service activity is carried out in the form of socialization to the community in Kelurahan Sialang Munggu by visiting residents' homes and visiting the market using the lecture method. Then proceed with distributing brochures containing the importance of using masks and implementing the COVID-19 health protocol, and the ending with distribution of free masks. Based on the community service activities that have been implemented, it can be concluded that this service activity can increase public understanding of the importance of using masks during the COVID-19 pandemic. So that in the future the quality of people's lives will increases.

Keywords: smart to using masks, COVID-19, kelurahan sialang munggu, new normal

Copyright (c) 2020 Puspa Ningrum, Husni Mubarak, Tyagita Widya Sari, Husnah

$\triangle$ Corresponding author

Address : Jalan Riau Ujung No.73 Pekanbaru

Email : puspa.ningrum@univrab.ac.id

ISSN 2721-9224 (Media Cetak)

Phone : 081537435568

ISSN 2721-9216 (Media Online)

DOI : https://doi.org/10.31004/abdidas.v1i5.97 


\section{PENDAHULUAN}

Badan Kesehatan Dunia (WHO) secara resmi menyatakan virus corona (COVID-19) sebagai pandemi global, tak terkecuali Indonesia. Semenjak pandemi COVID-19 melanda Indonesia, banyak daerah-daerah yang terkena dampaknya. Bukan hanya dari segi kesehatan saja yang terkena dampak, melainkan juga segi pendidikan, sosial budaya, dan perekonomian. Kasus positif corona dan angka kematian di Indonesia kian bertambah dari hari ke hari yang mengindikasikan bahwa pandemi belum dapat segera berakhir. Seperti halnya di Bumi Melayu Lancang Kuning (Riau), kasus positif corona terus mengalami lonjakan yang sangat tajam, bahkan dinilai berbagai kalangan nyaris sudah tak dapat terkendali lagi. Berdasarkan data sebaran suspek dan konfirmasi kasus COVID-19 di Provinsi Riau yang dikutip dari laman online, terdapat total 29.383 suspek dan total 6.120 konfirmasi untuk data hingga 24 September 2020 (Corona.riau.go.id, 2020).

Berbagai macam upaya untuk mengantisipasi penyebaran virus COVID-19 dan mengurangi jumlah penderita virus COVID-19 di Indonesia sudah dilakukan di seluruh daerah. Diantaranya dengan memberikan kebijakan membatasi aktifitas keluar rumah (Yunus \& Rezki, 2020). Aktivitas sosial dilarang dan ditunda sementara waktu, melemahnya ekonomi, pelayanan transportasi dikurangi dan diatur dengan ketat, pemerintah menutup tempat wisata, pusat perbelanjaan dan tempat hiburan sepi pengunjung, bahkan bekerja dan belajar pun dilakukan di rumah secara online (Syafrida \& Hartati, 2020). Oleh karena itu Pemerintah Provinsi (Pemprov) Riau berulang kali telah meminta kepada masyarakat luas agar benar-benar menerapkan protokol kesehatan COVID-19.

Penggunaan masker merupakan langkah antisipasi paling awal untuk mencegah penyebaran virus corona. Untuk itu penting bagi seluruh masyarakat Indonesia tanpa terkecuali untuk peduli dengan wabah yang sudah berlangsung hampir sekitar delapan bulan terakhir ini. Berkaitan dengan hal tersebut, pemerintah Kota Pekanbaru mengeluarkan Peraturan Walikota (Perwako) Pekanbaru Nomor 104 Tahun 2020 tentang "Pedoman Perilaku Hidup Baru Masyarakat Produktif dan Aman Dalam Pencegahan dan Pengendalian COVID-19 di Kota Pekanbaru". Namun nyatanya saat ini, masih banyak warga beraktivitas diluar rumah tanpa menggunakan masker. (Peraturan Walikota (Perwako) Pekanbaru Nomor 104, 2020).

Untuk mengatasi permasalahan tersebut, perlu dilakukan edukasi dan sosialisasi terhadap masyarakat dengan tujuan agar masyarakat khususnya warga Pekanbaru dapat memahami pentingnya menerapkan kebijakan yang telah ditetapkan pemerintah serta membiasakan diri dengan kehidupan baru (New Normal). Karena dalam hal ini butuh kesadaran dari seluruh elemen masyarakat untuk sama-sama melawan pandemi COVID-19. Berdasarkan bukti yang tersedia, COVID-19 ditularkan melalui kontak dekat dan droplet, bukan melalui transmisi udara. Orangorang yang paling berisiko terinfeksi adalah mereka yang berhubungan dekat dengan pasien COVID-19 atau yang merawat pasien COVID-19 
(Direktorat Jendral Pencegahan dan Pengendalian Penyakit, 2020).

Melalui kegiatan pengabdian masyarakat bersama mahasiswa yang turun langsung berinteraksi ke masyarakat dengan tetap menerapkan protokol COVID-19, dilaksanakanlah sosialisasi gerakan masyarakat cerdas menggunakan masker. Pengabdian masyarakat ini dimaksudkan sebagai upaya mengatasi permasalahan diatas dan menambah pengetahuan masyarakat tentang pentingnya menerapkan protokol kesehatan dimasa pandemi COVID-19. Dalam kegiatan sosialisasi dan pemberian masker gratis ini diharapkan masyarakat selalu disiplin menerapkan protokol kesehatan selama pandemi COVID-19, yaitu menggunakan masker, selalu menjaga jarak, dan sering mencuci tangan menggunakan sabun.

\section{METODE}

Kegiatan sosialisasi gerakan masyarakat cerdas menggunakan masker ini dilaksanakan di Kelurahan Sialang Munggu, Kecamatan Tampan, Kota Pekanbaru, Provinsi Riau yang berlangsung selama 2 hari di minggu awal bulan September 2020. Adapun sasaran kegiatan pengabdian masyarakat ini yaitu kelompok masyarakat di pasar yang ada dikelurahan tersebut serta para pegawai instansi pemerintahan di Kelurahan Sialang Munggu. Dalam kegiatan ini, diharapkan akan terwujud masyarakat tanggap COVID-19 dan dapat meminimalisir penyebaran virus corona.

Pemilihan lokasi pengabdian dilatarbelakangi karena masyarakat di Kelurahan
Sialang Munggu hidup secara bergotong royong, ini dibuktikan dengan mengikuti lomba yang diadakan pada tahun 2019 silam, Kelurahan Sialang Munggu sukses tampil perdana pada lomba bulan Bhakti Gotong Royong Masyarakat (BBGRM) tingkat kota pekanbaru (Detak satu.com, 2019). Lalu lembaga sosial menjadi pendorong partisipasi masyarakat dalam kegiatan pembangunan di daerah Kelurahan Sialang Munggu, seperti ikatan pemuda/I masjid atau mengadakan kegiatan ronda malam tiap RW. Sehingga dengan adanya pandemi COVID-19 ini sangat berdampak sekali terhadap aktivitas warga di Kelurahan Sialang Munggu. Kegiatan-kegiatan disekitar Kelurahan Sialang Munggu banyak terhenti, tidak ada nya kegiatan gotong royong, kegiatan ibu-ibu pkk dan wirid dimasjid, kegiatan mingguan ceramah, dan kegiatan pemuda/i diberhentikan sementara.

Kegiatan pengabdian masyarakat ini dilakukan sosialisasi terhadap masyarakat di Kelurahan Sialang Munggu dengan mendatangi rumah-rumah warga dan mendatangi pasar dengan menggunakan metode ceramah. Selanjutnya dilanjutkan dengan menyebarkan brosur berisi pentingnya menggunakan masker dan menerapkan protokol kesehatan COVID-19, serta diakhiri dengan pembagian masker gratis. Khusus untuk di instansi pemerintah di Kelurahan Sialang Munggu, diberikan tambahan pemberian berupa banner tentang infografis COVID-19. 


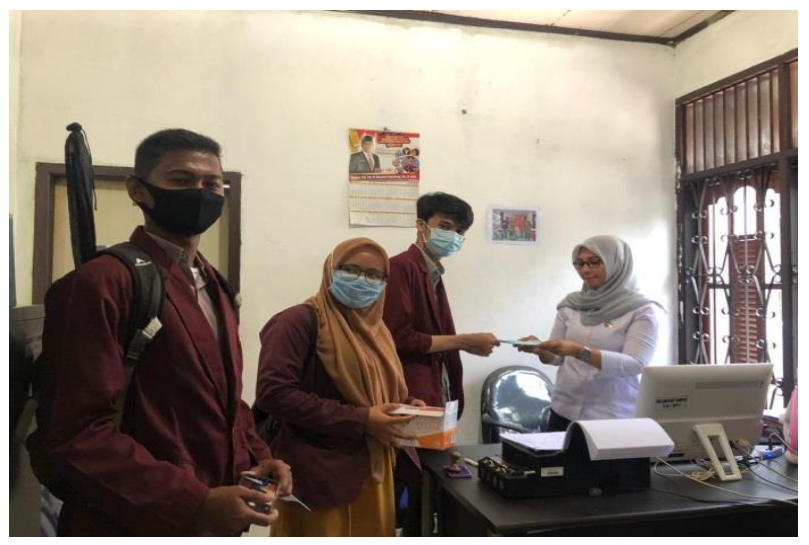

Gambar 1. Sosialisasi dan pemberian masker kepada instansi di Kelurahan Sialang Munggu

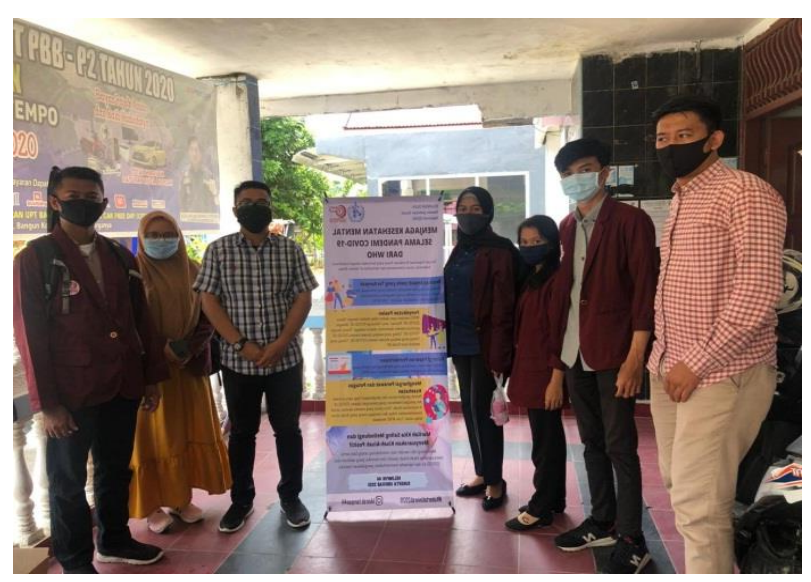

Gambar 2. Pemberian Banner infografis COVID19 di Kelurahan Sialang Munggu

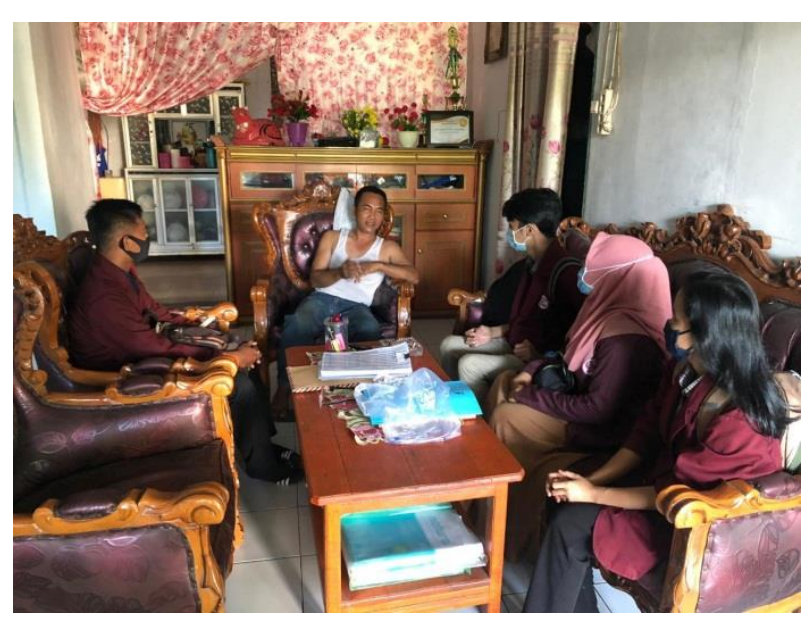

Gambar 3. Sosialisasi gerakan cerdas menggunakan masker pada warga

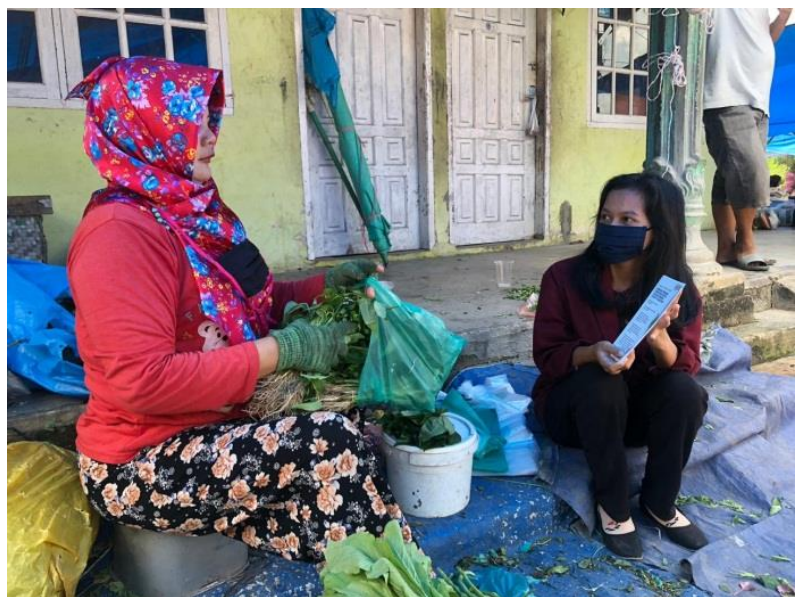

Gambar 4. Sosialisasi gerakan cerdas menggunakan masker pada masyarakat di pasar

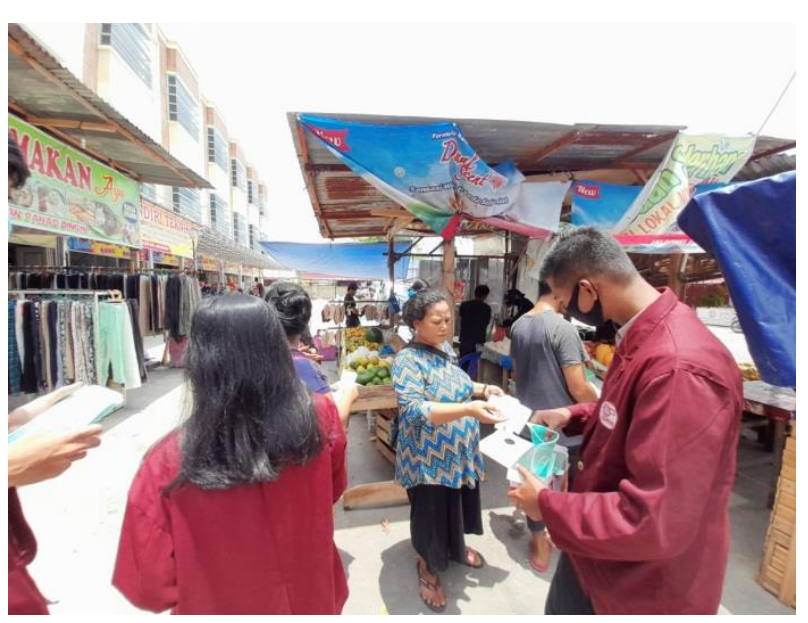

Gambar 5. Pemberian masker pada masyarakat di pasar

\section{HASIL DAN PEMBAHASAN}

COVID-19 merupakan penyakit yang baru ditemukan oleh karena itu pengetahuan terkait pencegahannya masih terbatas. Kunci pencegahan meliputi pemutusan rantai penularan dengan isolasi, deteksi dini, dan melakukan proteksi dasar meliputi (3M) menggunakan masker, mencuci tangan menggunakan sabun, dan menjaga jarak minimal 1 meter (Susilo et al., 2020).

Kegiatan pengabdian masyarakat yang dilaksanakan dalam bentuk sosialisasi langsung ke masyarakat tentunya dalam pelaksanaan 
menemukan beberapa kendala, dikarenakan sedang berada dalam masa pandemi COVID-19 yang membuat tim pengabdian beserta mahasiswa memiliki keterbatasan ruang gerak. Namun secara keseluruhan, kegiatan sosialisasi gerakan masyarakat cerdas menggunakan masker ini berjalan lancar dan mendapat respon positif dari warga di Kelurahan Sialang Munggu.

Sosialisasi gerakan masyarakat cerdas menggunakan masker ini tentunya dilaksanakan berdasarkan sumber yang valid. Menurut (World Health Organization, 2020) penggunaan masker yang benar diantaranya meliputi: (a) Menempatkan masker menutupi mulut dan hidung serta ikat dengan nyaman untuk meminimalkan celah antara wajah dan masker; (b) Saat digunakan, hindari menyentuh masker; (c) Lepaskan masker dengan menggunakan teknik yang benar yaitu tidak menyentuh bagian depan tetapi lepaskan tali pengikat dari belakang; (d) Segera ganti masker dengan masker baru yang bersih dan kering apabila masker lembab; (e) Jangan menggunakan kembali masker sekali pakai dan buang masker sekali pakai setelah digunakan.

Pada dasarnya sebenarnya masyarakat memahami betul pentingnya menggunakan masker dimasa pendemi COVID-19 seperti sekarang. Namun terkadang masih banyak warga yang tidak ingin memakai masker dengan alasan susah bernafas. Tetapi tim pengabdian beserta mahasiswa tetap memberikan solusi bagaimana menggunakan masker dengan baik dan nyaman, serta edukasi pentingnya upaya pencegahan terhadap virus corona.

\section{SIMPULAN}

Berdasarkan kegiatan yang telah dilakukan dapat disimpulkan bahwa kegiatan pengabdian ini dapat meningkatkan pemahaman masyarakat mengenai pentingnya menggunakan masker dimasa pandemi COVID-19. Sehingga untuk selanjutnya kualitas kehidupan masyarakat akan meningkat.

\section{UCAPAN TERIMA KASIH}

Pengabdian masyarakat ini tidak bisa dijalankan jika tidak bekerja sama dengan pihakpihak terkait. Untuk itu, ucapan Terima kasih disampaikan kepada LPPM Universitas Abdurrab, Masyarakat Kelurahan Sialang Munggu, serta Instansi Pemerintah Kelurahan Sialang Munggu yang telah berkontribusi dalam kegiatan pengabdian masyarakat ini.

\section{DAFTAR PUSTAKA}

Corona.riau.go.id. (2020). Data sebaran Suspek \& Konfirmasi COVID-19 Provinsi Riau. 24 September 2020. https://covid19.riau.go.id/sebaran/peta/202009-24/1600991698-realtime-corona-riau.jpg

Detak satu.com. (2019). Kelurahan Sialang Munggu Sukses Tampil Perdana di Lomba BBGRM Pekanbaru. 20 September 2020. http://detaksatu.com/2019/07/29/kelurahansialang-munggu-sukses-tampil-perdana-dilomba-bbgrm-pekanbaru/

Direktorat Jendral Pencegahan dan Pengendalian Penyakit. (2020). Pedoman Pencegahan dan Pengendalian Coronavirus Disease (Covid19) (p. 12). Kementerian Kesehatan Republik Indonesia.

Peraturan Walikota (Perwako) Pekanbaru Nomor 104. (2020). Pedoman Perilaku Hidup Baru Masyarakat Produktif dan Aman Dalam Pencegahan dan Pengendalian Covid-19 di 
Kota Pekanbaru.

Susilo, A., Rumende, C. M., Pitoyo, C. W., Santoso, W. D., Yulianti, M., Herikurniawan, H., Sinto, R., Singh, G., Nainggolan, L., \& Nelwan, E. J. (2020). Coronavirus Disease 2019: Tinjauan Literatur Terkini. Jurnal Penyakit Dalam Indonesia, 7(1), 45-67.

Syafrida, S., \& Hartati, R. (2020). Bersama Melawan Virus Covid 19 di Indonesia. SALAM: Jurnal Sosial Dan Budaya Syar-I, 7(6), 495-508.

World Health Organization, 2019 (2020).

Yunus, N. R., \& Rezki, A. (2020). Kebijakan Pemberlakuan Lock Down Sebagai Antisipasi Penyebaran Corona Virus Covid19. Salam: Jurnal Sosial Dan Budaya Syar-I, 7(3), 227-238. 